\title{
粒子集合体モデルに基づくフレッシュモルタルの変形抵抗性に及ぼす 応力状態および載荷持続時間の影響に関する研究 \\ STUDY ON EFFECTS OF STRESS STATE AND LOADING TIME ON DEFORMATION RESISTANCE OF FRESH MORTAR
}

\author{
李＼cjkstart柱＼cjkstart国*，谷川恭雄**，森＼cjkstart博 嗣***，黒川善 幸**** \\ Zhuguo LI, Yasuo TANIGA WA, Hiroshi MORI \\ and Yoshiyuki KUROKAWA
}

\begin{abstract}
In this paper, the effects of stress state and loading time on deformation resistance of fresh mortar are investigated quantitatively, and the relational formulas between shearing strain rate and shearing stress, mean principal stress as well as loading time are induced by applying the mechanical constitutive law which the authors have already proposed on the assumption that fresh mortar is a kind of particle assembly. Moreover, the formulas for calculating apparent viscosity are given, which is defined as the ratio between shearing stress and shearing strain rate. As the results, (1) Shearing strain rate becomes higher with the increase of shearing stress in each stress state. (2) Shearing strain rate drops off with loading time in visco-elastic state and visco-elasto-plastic state, but increases in failure state. (3) Shearing strain rate decreases with the increase of mean principal stress in each stress state. And these results are verified by a series of shearing tests using mortar which is in from dry state to high flowing state.
\end{abstract}

Keywords : apparent viscosity, shearing strain rate, constitutive law, effect of stress state, effect of loading time, fresh mortar 見かけの粘性係数, せん断ひずみ速度, 構成則, 応力状態の影響, 載荷持続時間の影響, フレッシュモルタル

\section{1.はじめに}

現在、フレッシュモルタルまたはコンクリートのレオロジー的な 研究のほとんどは、コンクリートを均質な連続体とみなし、降伏し た後の高いせん断ひずみ速度領域のみに着目して、せん断応力と せん断ひずみ速度の関係を近似的に直線と仮定したビンガムモデル を用いて、流動性の評価・管理を試みている ${ }^{11.213 \%}$

しかし、フレッシュコンクリートが正確にビンガムモデルで表現 されるような単純な性状を有しているとは限らない。多くの実験結 果によれば、せん断応力が降伏值を超えると、せん断応力の増加に 伴ってせん断ひずみ速度が増大し、両者の関係は、一般にせん断応 力軸に対して凸の曲線となる31.4\%。またフレッシュコンクリート

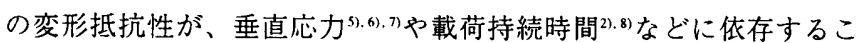
とが定性的に確認されているが、まだ定量化される段階には至って いない。そのため、回転粘度計、球引上げ粘度計、平行板ブラスト メー夕、せん断ボックス試験器》などによって求めたレオロジー定 数の各測定結果を直接比較することができず。また、標準的な計測 方法はまだ確立されていない3110\%。

フレッシュコンクリートの流動性状を定量的に評価し、またその 作業性を解析的に予測するためには、その変形挙動に関するより詳 細な検討を行い、レオロジー定数の影響要因とその傾向を定量的に 把握する必要がある゙”。

筆者らは、既にEyringの粘性理論"を拡張し、村山の剛体粒子集 合体の力学挙動の理論 ${ }^{22}$ (以下、村山の理論と略称)に基づき、せん 断応力ーひずみ一載荷持続時間－環境温度の関係式を誘導するこ とによって、フレッシュモルタルを粒子集合体とみなした場合の カ学モデルを提案した ${ }^{13)}$ 。本研究では、この力学モデルを用い
て、フレッシュモルタルの変形抵抗性および粘性係数の影響要因 について検討する。

\section{2. フレッシュモルタルの構成則に関する既往の研究 ${ }^{13)}$}

2.1 力学モデル

練混ぜ直後のモルタルは、水、結合材および骨材で構成され、次 の2種類の粒子群を含む粒子集合体とみなすことができる。

1) S1粒子(骨材)：相対変位挙動が時間に依存せず、境界面におい ては Coulomb の摩擦法則に従う滑動抵抗を示す。

2) S2粒子(セメント)：相対变位挙動が時間に依存し、滑動抵抗と 粘性抵抗を示す。

ここでは、両粒子群が、互いに独立してフレッシュモルタルの変 形に寄与するものと仮定する。

フレッシュモルタルの状態は、せん断応力がある限界 $\tau_{0}$ を超え、 その増加に伴って、粘弾性状態、粘弾塑性状態、破壊状態の順に移 行する。各状態ごとの載荷応力 $\tau$ と $S_{1} 、 S_{2}$ 粒子群の諸抵抗の釣合い関 係、および各粒子群のせん断ひずみと載荷応力の関係は、次のよj になる。なお、S1、S2粒子の区別は添字1,2で示す。

(1) 粘弾性状態： $\tau_{0}<\tau \leqq \tau_{\ell \ell}, \gamma_{1} \leqq\left(\gamma_{\ell \ell}\right) 1, \gamma_{2} \leqq\left(\gamma_{\ell \ell}\right) 2$

$\tau=G_{01} \gamma_{e l}=\tau_{0}+\tau_{e 2}+G_{02} \gamma_{e 2}, \tau_{e 2}=\eta_{e}\left(\mathrm{~d} \gamma_{e 2} / \mathrm{d} t\right), \gamma=\gamma_{1}+\gamma_{2}$,

$\gamma_{e \ell}=\left(\gamma_{\ell \ell}\right)_{1}+\left(\gamma_{\ell \ell}\right)_{2}=\tau_{\ell \ell} / G_{01}+\tau_{\ell \ell} / G_{02}, \quad \gamma_{1}=\gamma_{e l}, \quad \gamma=\gamma_{e 2}$

ここに、 $\gamma$ : 粒子集合体のせん断ひずみ、 $\tau_{\ell \ell}$ : 粒子集合体の粘弾性 限界、 $\gamma_{e \ell}$ : 粒子集合体の粘弾性限界せん断ひずみ、 $\gamma_{1}, \gamma_{2}$ : それぞれ $\mathrm{S}_{1}, \mathrm{~S}_{2}$ 粒子群のせん断ひずみ、 $\gamma_{e}$ : せん断粘弾性ひ ずみ、 $\tau_{0}: \mathrm{S} 2$ 粒子の初期の接点結合強度、Go: せん断弾性 係数、 $\eta_{e}:$ 粘弾性状態の粘度

\footnotetext{
* 名古屋大学工学研究科建築学尃攻 大学院生. 工修

** 名古屋大学工学研究科建築学尃攻 教授・ 工博

*** 名古屋大学工学研究科建築学尃攻 助教授. 工博

**** 名古屋大学工学研究科建築学尃攻 助手. 工修
}

Graduate Student, Dept. of Architecture, Graduate School of Engineering, Nagoya Univ., M. Eng.

Prof., Dept. of Architecture, Graduate School of Engineering, Nagoya Univ. Dr. Eng.

Assoc. Prof., Dept. of Architecture, Graduate School of Engineering, Nagoya Univ., Dr. Eng. Research Assoc., Dept. of Architecture, Graduate School of Engineering, Nagoya
Univ., M. Eng. 


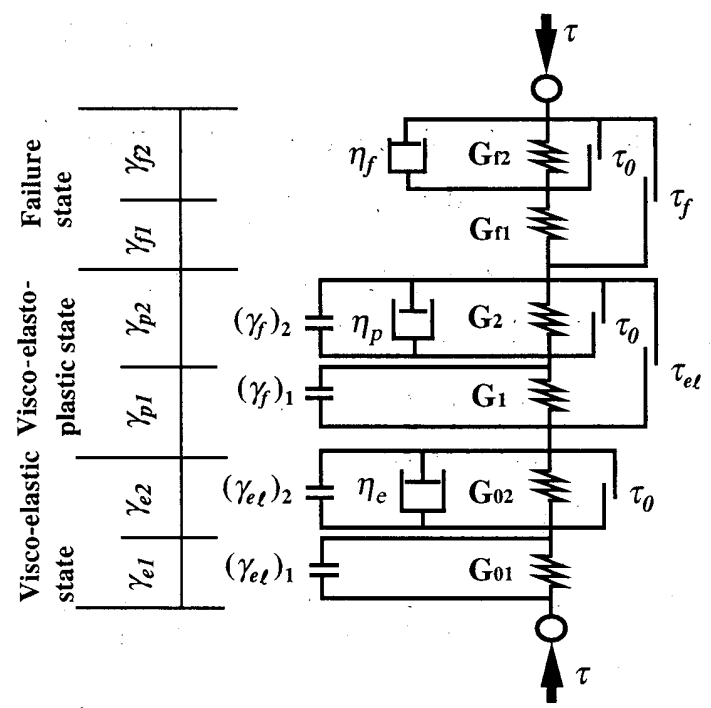

Fig. 1 Mechanical model of fresh mortar

(2) 粘弾塑性状態 : $\tau_{\ell \ell}<\tau \leqq \tau_{f},\left(\gamma_{\ell \ell}\right)_{1}<\gamma_{I} \leqq\left(\gamma_{f}\right)_{1},\left(\gamma_{\ell \ell}\right)_{2}<\gamma_{2} \leqq\left(\gamma_{f}\right)_{2}$ $\tau=\tau_{\ell \ell}+G_{1} \gamma_{p l}=\tau_{0}+\tau_{\ell \ell}+\tau_{p 2}+G_{2} \gamma_{p 2}$,

$\gamma_{I}=\left(\gamma_{e \ell}\right) 1+\gamma_{p l}, \gamma_{2}=\left(\gamma_{e \ell}\right) 2+\gamma_{p 2}, \tau_{p 2}=\eta_{p}\left(\mathrm{~d} \gamma_{p 2} / \mathrm{d} t\right)$

ここに、 $\tau_{f}$ : 粒子集合体のせん断破壊強度、 $\gamma_{p}$ : せん断粘弾塑性ひ ずみ、 $\left(\gamma_{f}\right) 1,\left(\gamma_{f}\right) 2$ : 破壊開始点のS $1, \mathrm{~S}_{2}$ 粒子群のせん断ひず み、 $G:$ 粘弾性限界点を割線の原点とする割線せん断弾性 係数、 $\eta_{p}:$ 粘弾塑性状態の粘度

(3) 破壊状態: $\tau>\tau_{f}, \gamma_{2}>\left(\gamma_{f}\right)_{2}$

$\tau=\tau_{f}+G_{f l} \gamma_{f 1}=\tau_{0}+\tau_{f}+\tau_{f 2}+G_{f 2} \gamma_{f 2},\left(\gamma_{f}\right)_{1}=\left(\gamma_{\ell \ell}\right)_{1}+\left(\tau_{f}-\tau_{\ell \ell}\right) / G l$ $\left(\gamma_{f}\right)_{2}=\left(\gamma_{e \ell}\right)_{2}+\left(\tau_{f}-\tau_{0}-\tau_{f 2}-\tau_{e \ell}\right) / G_{2}, \tau_{f 2}=\eta_{f}\left(\mathrm{~d} \gamma_{f_{2}} / \mathrm{d} t\right)$,

$\gamma_{l}=\left(\gamma_{f}\right)_{1}+\gamma_{f l}, \gamma_{2}=\left(\gamma_{f}\right)_{2}+\gamma_{f 2}, \gamma_{f}=\left(\gamma_{f}\right)_{1}+\left(\gamma_{f}\right)_{2}$

ここに、 $\gamma_{f l}, \gamma_{f 2}$ : 破壞状態における両粒子群のせん断ひずみ、 $G_{f}$ : 破壊開始点を原点とするせん断弾性係数、 $\eta_{r}$ : 破壊状態の 粘度、 $\gamma_{f}:$ 破壊開始点の粒子集合体のせん断ひずみ

式(2-1 3)に示す応力ーひずみ一時間の関係式、すなわち構成則 は、Fig.1のような力学モデルで表現できる。モデル中のパラメタ は、モルタルのコンシステンシーによって異なる。

\section{2 各状態における $S_{2}$ 粒子群のせん断ひずみ}

S2粒子群が粒子集合体に寄与するひずみは、載荷持続時間に依存 するので、Eyringの粘性理論"1を拡張し、村山の理論"21および上述し た力学モデルにより、次のように求められる゙3。

(1) 粘弾性状態:

$$
\gamma_{e 2}=\frac{\tau-\tau_{0}}{G_{02}}+\frac{\left(\tau-\tau_{0}\right)}{B_{e} G_{02}} \ln \left[R_{e} t / \sqrt{1+\left(\tau / \sigma_{m}\right)^{2}}\right]
$$

ここに、Re=Ae $B_{e} c_{\varphi} G 02, A_{e}=A b \Lambda N_{2}, B_{e}=\Lambda /\left(2 N_{2} b k T\right), b=W_{e} / \sigma_{m}, A=$ $(k T / h) \exp (-E 0 / k T) 、 k:$ ボルツマン定数、 $h:$ プランク定数、 $E_{o}:$ エネルギ障壁の高さ、 $T$ : 絶対温度、 $c_{\varphi}=\cos \varphi 、 \varphi:$ 粒 子間の摩擦角の平均檤、 $\Lambda$ : 粘弾性状態における滑動粒子 の単位時間当りの平均移動距離、 $N_{2}$ : 単位面積における粘 性粒子の個数、We : 弾性限界の大きさに無関係な定数, $\sigma_{\mathrm{m}}$ : 最大せん断応力面上の垂直応力 (平均主応力) 、 $t: \mathrm{S}_{2}$ 粒子群 に変位が生じた後の経過時間、てoが小さくて無視できる場 合には、載荷持続時間に等しい。
上式が成立する条件は、式(2-5)で表される。 $y_{e 2}$ は、式(2-5)の限界

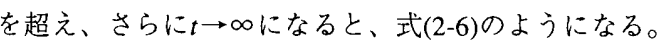

$$
\begin{aligned}
& 0 \leq \gamma_{e 2} \leq \frac{B_{e}-2}{B_{e} G_{02}}\left(\tau-\tau_{0}\right) \\
& \left(\gamma_{e 2}\right)_{t \rightarrow \infty}=\left(\tau-\tau_{0}\right) / G_{02}
\end{aligned}
$$

(2) 粘弾塑性状態：

$$
\gamma_{p 2}=\frac{v \tau_{r}\left[\frac{1}{v \alpha}-\delta+\ln \left\{R_{p}\left(t-t_{e \ell}\right) / \sqrt{1+\left(\tau / \sigma_{m}\right)^{2}}\right\}\right]}{G_{02}\left[2+\delta-\ln \left\{R_{p}\left(t-t_{e \ell}\right) / \sqrt{1+\left(\tau / \sigma_{m}\right)^{2}}\right\}\right]}
$$

ここに、 $\alpha=\tau_{21} /\left(v B p \tau_{r}\right), \delta=-B_{p}\left(\tau-\tau 0-\tau_{\ell \ell}-\tau_{r}\right) / \tau_{21} 、 t e \ell: \mathrm{S} 2$ 粒子群の寄 与するひずみ $\gamma_{2}$ が $\left(\gamma_{\ell \ell}\right) 2$ に達するまでの載荷持続時間、 $\tau_{i f}$ ： 見かけの破壊強度、 $R_{p}=A_{p} B_{p} G 02 c_{\varphi} / v, A_{p}=A b^{\prime} \Lambda_{p} N_{2}$, $B_{p}=\Lambda_{p} /\left(2 N_{2} b^{\prime} k T\right), b^{\prime}=\left(1+v_{0}\right) W_{e} / \sigma_{m}, v=1+k_{d} v_{0}, \Lambda_{p}:$ 粘弾塑 性状態に打ける移動粒子群の単位時間当りの平均移動距 離、 $\Lambda_{p}=\left(1+v_{0} k_{d}\right) \Lambda /\left(1+v_{0}\right) 、 \tau_{r}$ : 破壊時の残留強度、 $v_{0}, k_{d}$ : 比例定数、 $\tau_{21}=\tau_{r} \ln \left\{\tau_{r} /\left(\tau_{i f}-\tau\right)\right\}+\left(1+v_{0}\right)\left(\tau_{e \ell}-\tau_{0}\right)$

(3) 破壊状態：

$\therefore_{f 2}^{\prime}=F_{1}\left[\exp \left\{F_{2}\left(t-t_{f}\right)\right\}-1\right] / F_{2}$

$$
\text { ここに、 } F_{1}=A_{f} \exp \left[\frac{B_{f}}{N_{2}}\left(\tau-\tau_{f}\right)\right], F_{2}=\frac{B_{f}}{N_{2}} H \exp \left[\frac{B_{f}\left(\tau-\tau_{f}\right)}{N_{2}}\right],
$$

$H=A k_{f} \Lambda_{f} N_{2} \tau_{c}, A_{f}=A \Lambda_{f} N_{2}, B_{f}=\Lambda_{f} /(2 k T) 、 k_{f}$ : 比例定 数、 $\Lambda_{f}$ : 破壊状態における移動粒子群の単位時間当りの 平均移動距離、 $\tau_{c}=\tau_{f}-\tau_{r}, t_{f}$ : 破壊時点の載荷持続時間

\section{3. せん断ひずみ速度の影響要因に関する理論的考察}

\section{1 各状態におけるせん断ひずみ速度}

粘着性をもたないS 1 粒子群のせん断ひずみは、載荷持続時間に依 存しないため、粒子集合体のせん断ひずみ速度は、S2粒子群のせん 断ひずみ速度に等しい。

(1) 粘弾性状態 :

式(2-4)を載荷持続時間 $t$ について微分すると、粘弾性状態における フレッシュモルタルのせん断ひずみ速度として、式(3-1)が得られる。

$$
\frac{\mathrm{d} \gamma_{e}}{\mathrm{~d} t}=\frac{\tau-\tau_{0}}{H_{I} G_{02} \sigma_{m} t}
$$

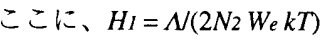

式(3-1)によれば、粘弾性状態におけるせん断ひずみ速度は、せん断 応力がて。以上のとき、せん断応力に正比例して直線的に増加する。

(2) 粘弾塑性状態 :

式(2-7)を載荷持続時間 $t$ について微分する。さらに、付録に詳述 するように式(2-7)を解いて近似すると、式(3-2)が得られる。

$$
\begin{gathered}
\ln \frac{\mathrm{d} \gamma_{p 2}}{\mathrm{~d} t}=\ln H_{2}+H_{3} \tau-\ln \left(t-t_{e \ell}\right) \\
\text { ここに、 } H_{2}=\frac{v \tau_{r}^{2} \tau_{22}}{G_{02} B_{p} \tau_{i f}^{n}}, n=2+\frac{\tau_{r}}{\tau_{22}}, H_{3}=\frac{n}{\tau_{i f}}, \\
\tau_{22}=\tau_{r} \ln \left(\tau_{i f}-\tau_{e \ell}\right)+\left(1+v_{0}\right)\left(\tau_{e \ell}-\tau_{0}\right)
\end{gathered}
$$

式(3-2)を書き換え、粘弾塑性状態におけるフレッシュモルタルの せん断ひずみ速度を、式(3-3)のように求める。

$$
\frac{\mathrm{d} \gamma_{p}}{\mathrm{~d} t}=\frac{\mathrm{d} \gamma_{p 2}}{\mathrm{~d} t}=H_{2}\left(t-t_{e \ell}\right)^{-1} \exp \left(H_{3} \tau\right)
$$

式(3-2, 3)より、粘弾塑性状態におけるせん断ひずみ速度は、せん 
断応力の増加に伴って大きくなる。両者の関係は指数曲線で表さ れ、片対数グラフ上では直線となる。

(3) 破壊状態:

式(2-8)を載荷持続時間 $t$ について微分すると、破壊状態における フレッシュモルタルのせん断ひずみ速度として、式(3-4)が求められ る。

$$
\frac{\mathrm{d} \gamma_{f}}{\mathrm{~d} t}=\frac{\mathrm{d} \gamma_{f 2}}{\mathrm{~d} t}=A_{f} \exp \left[\frac{B_{f}}{N_{2}}\left(\tau-\tau_{f}\right)+H_{4} \tau_{c} \exp \left\{\frac{B_{f}\left(\tau-\tau_{f}\right)}{N_{2}}\right\}\left(t-t_{f}\right)\right]
$$

$$
\text { ここに、 } H_{4}=A k_{f} \Lambda_{f} B_{f}
$$

式(3-4)の両辺を対数に取ると、次式となる。

$$
\ln \frac{\mathrm{d} \gamma_{f}}{\mathrm{~d} t}=\ln A_{f}+\frac{B_{f}}{N_{2}}\left(\tau-\tau_{f}\right)+H_{4} \tau_{c} \exp \left\{\frac{B_{f}\left(\tau-\tau_{f}\right)}{N_{2}}\right\}\left(t-t_{f}\right)
$$

式(3-4)より、破壊状態においては、せん断ひずみ速度はせん断応 力の増加とともに増加し、両者の関係は指数曲線となる。式(3-5)中 の第3項は、第2項に比べてかなり小さいため、これを無視すると、 両者の関係図は、片対数グラフ上で直線に近似できる。

\section{2 載荷持続時間の影響}

(1) 粘弾性状態 :

式(3-1)によれば、粘弾性状態におけるせん断ひずみ速度は、載荷 持続時間に反比例する。式(3-1)の両辺を対数に取ると、式(3-6)が得 られる。

$$
\ln \frac{\mathrm{d} \gamma_{e}}{\mathrm{~d} t}=\ln \left(\frac{\tau-\tau_{0}}{H_{l} G_{02}}\right)-\ln t-\ln \sigma_{m}
$$

一定のせん断応力に対して、粘弾性状態のせん断ひずみ速度と載 荷持続時間の関係は、両対数グラフ上で右下りの直線となる。

(2) 粘弾塑性状態 :

式(3-2,3)によれば、粘弾塑性状態では一定のせん断応力下のせん 断ひずみ速度は、載荷持続時間の増加に伴って小さくなる。両者の 関係は、両対数グラフ上で右下りの直線となる。

(3) 破壊状態:

式(3-4, 5)によれば、破壊状態におけるせん断ひずみ速度は、載荷 持続時間とともに指数曲線的に増加する。両者の関係は、片対数グ ラフ上で右上がりの直線で表される。

Fig. にに示した力学モデルより明らかなように、粘弾性限界以上の せん断応力 $\tau$ が作用したとき、フレッシュモルタルの状態は、載荷 持続時間の増加に伴って移行する。したがって、 $\mathrm{d} \gamma / \mathrm{d} t-t$ 関係のグラ フは、粘弾性限界以下の一定のせん断応力が作用するときは、両対 数グラフ上で1本の右下りの直線であり、粘弾性限界から破壊強度ま での範囲で一定のせん断応力が作用するときには、2本の右下りの直 線となる。また、破壊強度以上になると、 $\mathrm{d} \gamma / \mathrm{d} t-t$ 関係のグラフは、 三つの領域に分けられ、最後の部分が片対数グラフ上で右上がりの 直線で表される。

\section{3 垂直応力の影響}

フレッシュモルタルでは、粉体の内部摩擦が無視できないため、 その変形挙動は応力状態に依存する ${ }^{31,40}$ 。本研究では、粒子集合体中 の最大せん断応力面に作用する垂直応力、すなわち平均有効応力が その変形挙動に及ほす影響について検討する。

村山の理論(2)によれば、粒子集合体の力学挙動はその粒子配列に
支配され、粒子配列は、最大せん断応力面に沿う粒子の滑動抵抗角 (粒子接点角と粒子間摩擦角の和)の分布およびその中央值で表され る。また、筆者らの研究 ${ }^{14) 15}$ によって、粒子集合体が負担できる応 力比 $Z\left(=\tau / \sigma_{m}\right)$ の值は、その時点における全粒子の平均滑動抵抗角の 正接值に等しい。粘弾性限界、破壊限界および全破壊状態におい て、粒子集合体が負担できる応力比は、粒子材料および試料を作成 した締固め応力によって決定される粒子配列に特有な粒子滑動抵抗 角に対応する定数である。したがって、式(3-7)が得られる。

$\tau_{e \ell}=Z_{e} \ell \sigma_{m}, \tau_{f}=Z_{f} \sigma_{m}, \tau_{i f}=Z_{i f} \sigma_{m}, \tau_{r}=Z_{r} \sigma_{m}$

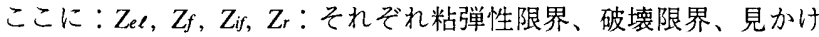
の破壊限界および全破壊状態における粒子集合体が負担で きる応力比(定数)

一方、 $\tau_{0}$ は、載荷する前のセメントの水和生成物による $\mathrm{S}_{2}$ 粒子の 初期の接点結合強度で、材料の品質と静置時間が一定であれば、垂 直応力にかかわらず定数となり、特に、普通セメントを使用した練 混ぜ直後のモルタルでは、 $\tau_{0}$ の值は極めて小さく、無視できると考 えられる。

なお、村山の理論 ${ }^{21}$ によれば、S2粒子群のせん断弾性係数G02 は、 垂直応力 $\sigma_{m}$ の増加に伴って比例的に増加し、式(3-8)で表される。

$$
G_{02}=3 \sigma_{m} /\left(2 \sqrt{2} c_{e} N_{2} \Lambda W_{e}\right)
$$

(1) 粘弾性状態:

式(3-8)を式(3-1)式に代入して、式(3-9)を得る。

$$
\frac{\mathrm{d} \gamma_{e}}{\mathrm{~d} t}=\frac{\tau-\tau_{0}}{V_{1} \sigma_{m}^{2} t}
$$

ここに、 $V_{1}=3 / 4 \sqrt{2} c_{e} N_{2}^{2} W_{e}^{2} k T$

上式の両辺を対数に取ると、式(3-10)が得られる。

$$
\ln \frac{\mathrm{d} \gamma_{e}}{\mathrm{~d} t}=\ln \frac{\tau-\tau_{0}}{V_{1} t}-2 \ln \sigma_{m}
$$

式(3-10)によれば、粘弾性状態において、せん断ひずみ速度は垂直 応力の増加とともに減少する。両対数グラフ上で、両者の関係図は 右下りの直線となる。

(2) 粘弾塑性状態:

式(3-7)、(3-8)を、式(3-2)に示した $H_{2}$ 值の式に代入し、て 0 を無視す ると、式(3-11)が得られる。

$$
\begin{aligned}
& H_{2}= \frac{Z_{r}^{3}\left(\ln \sigma_{m}+V_{3}\right)}{V_{2} Z_{i f}^{n} \sigma_{m}^{n-1}} \\
& \text { ここに、 } V_{2}=3 /\left[4 \sqrt{2} c_{e}\left(1+v_{0}\right)^{2} N_{2}^{2} W_{e}^{2} k T\right], \\
& V_{3}=\ln \left(Z_{i f}-Z_{e \ell}\right)-\left(1+v_{0}\right) Z_{e \ell} / Z_{r}
\end{aligned}
$$

式(3-11)を式(3-3)に代入すると、粘弾塑性状態におけるせん断ひ ずみ速度と垂直応力の関係を、式(3-12)のように表すことができる。

$$
\begin{aligned}
& \frac{\mathrm{d} \gamma_{p}}{\mathrm{~d} t}=\frac{V_{4}\left(\ln \sigma_{m}+V_{3}\right)}{\left(t-t_{e \ell}\right) \sigma_{m}^{n-1}} \exp \left(\frac{n \tau}{Z_{i f} \sigma_{m}}\right) \\
& \text { ここに、 } V_{4}=Z_{r}^{3} / V_{2} Z_{i f}^{n} \\
& \text { 上式の両辺を対数に取ると、式(3-13)になる。 } \\
& \quad \ln \frac{\mathrm{d} \gamma_{p}}{\mathrm{~d} t}=\ln \left(\ln \sigma_{m}+V_{3}\right)-\ln \sigma_{m}+\frac{n \tau}{Z_{i f}} \frac{1}{\sigma_{m}^{n-1}}+\ln \left(\frac{V_{4}}{t-t_{e \ell}}\right)
\end{aligned}
$$

式(3-13)によれば、せん断ひずみ速度は垂直応力とともに小さくな る。元e 以上のせん断応力に対して、両者の関係は片対数グラフ上で 
双曲線で表される。

(3) 破壊状態 :

式(3-7)を式(3-4)、(3-5)に代入し、対数に取って、それぞれ式 (3-14)、(3-15)を得る。

$$
\begin{aligned}
& \frac{\mathrm{d} \gamma_{f}}{\mathrm{~d} t}=A_{f} \exp \left[\frac{B_{f}}{N_{2}} \tau-\frac{B_{f} Z_{f}}{N_{2}} \sigma_{m}+V_{5} \sigma_{m} \exp \left(\frac{B_{f}\left(\tau-Z_{f} \sigma_{m}\right)}{N_{2}}\right)\left(t-t_{f}\right)\right] \\
& \text { ここに、V } V_{5}=H_{4}\left(Z_{f}-Z_{r}\right) \\
& \ln \frac{\mathrm{d} \gamma_{f}}{\mathrm{~d} t}=\ln A_{f}+\frac{B_{f}}{N_{2}} \tau-\frac{B_{f} Z_{f}}{N_{2}} \sigma_{m}+V_{5} \sigma_{m} \exp \left(\frac{B_{f}\left(\tau-Z_{f} \sigma_{m}\right)}{N_{2}}\right)\left(t-t_{f}\right)
\end{aligned}
$$

Vsは非常に小さく、式(3-15)の右辺の第4項の $\sigma_{m}$ に伴う変化は第3 項の変化に比べて無視できるほど小さいため、破壞状態におけるせ ん断ひずみ速度は、垂直応力の増加に伴って小さくなる。両者の関 係図は、片対数グラフ上で近似的に右下りの直線となる。

\section{4. 粘性係数}

一般に、物体が周囲の物質に対して相対的に移動しているときに 粘性抵抗を受ける。フレッシュモル夕ルのような粒子集合体では、 粒子間の摩擦が無視できないため、せん断変形をしているときに、 必ずしもすべての粒子が相対移動をしているとは限らない。したが って、フレッシュモルタルでは、摩擦性滑動抵抗に打ち勝って相対 移動をするセメント粒子の滑り接点のみで、粘性抵抗が発揮され る。粘性抵抗応力は、S2粒子群(セメント粒子群)が受けた総せん断 応力から摩擦性滑動抵抗を差し引いた残りの抵抗応力に相当する。 この粘性抵抗応力と $\mathrm{S} 2$ 粒子群のせん断ひずみ速度の比は、移動状態 にある粘着性粒子接点に現れる真の粘性係数の平均值であり、この 值を S2 2 粒子群の粘性係数と呼ぶ。この粘性係数は、Fig.1に示すダッ シュポット $\eta_{e} 、 \eta_{p} 、 \eta_{f}$ で表される。セメント粒子の接点の微視的構 造特性抢よび変位挙動を解明するには、S2粒子群の粘性係数が有用 なパラメ夕になるものと考えられる。

本研究では、フレッシュモルタルが受ける総せん断応力とそのせ ん断ひずみ速度の比をフレッシュモルタルの見かけの粘性係数と呼 び、 $\eta_{a}$ と記する。フレッシュモルタルの品質の定量的な評価および 作業性の解析的な予測には、試料のマクロな挙動を表す見かけの粘 性係数を用いるのが実用的である。以下では、フレッシュモルタル の見かけの粘性係数について考察を行う。

(1) 粘弾性状態:

式(3-9)によって、粘弾性状態におけるフレッシュモルタルの見か けの粘性係数和は、式(4-1)のように求められる。

$$
\eta_{a e}=\frac{V_{1} \sigma_{m}^{2} t}{1-\tau_{0} \tau}
$$

上式より、見かけの粘性係数は、垂直応力および載荷持続時間の 増加に伴って大きくなる。 $\eta_{a e}$ は、珨が小さくて無視できる場合に は、せん断応力にかかわらない定数であり、五が無視できない大き さの場合には、せん断応力の増加とともに減少する。

(2) 粘弾塑性状態 :

式(3-12)によって、粘弾塑性状態におけるフレッシュモルタルの見 かけの粘性係数 $\eta_{a p}$ は、式(4-2)のように得られる。

$$
\eta_{a p}=\frac{\left(t \cdot-t_{e \ell}\right) \sigma_{m}}{V_{4}\left(\ln \sigma_{m}+V_{3}\right)} \frac{\tau}{\exp \left(n \tau / Z_{i f} \sigma_{m}\right)}
$$

上式によって、見かけの粘性係数 $\eta_{a p}$ は、載荷持続時間および垂直 応力の増加とともに大きくなり、せん断応力の増加に伴って急速に 減少する。

(3) 破壊状態 :

式(3-14)より、破壊状態におけるフレッシュモルタルの見かけの粘 性係数 $\eta_{a f}$ は、式(4-3)のようになる。

$$
\eta_{a f}=\frac{\tau}{A_{f} \exp \left[\frac{B_{f}}{N_{2}} \tau-\frac{B_{f} Z_{f}}{N_{2}} \sigma_{m}+V_{5} \sigma_{m} \exp \left(\frac{B_{f}\left(\tau-Z_{f} \sigma_{m}\right)}{N_{2}}\right)\left(t-t_{f}\right)\right]}
$$

上式によれば、見かけの粘性係数 $\eta_{a f}$ は、垂直応力とともに増加 し、載荷持続時間およびせん断応力の増加に伴って減少する。

\section{5. せん断ひずみ速度の影響要因に関する実験的考察}

試作のせん断試験装置13)を用いて、Table 1に示す2種のフレッシュ モルタルを試料として、異なる条件下のせん断ひずみ速度の測定を 行い、上述した理論解析結果の妥当性を検証した。

\section{1 実倹概要}

Fig. 2 にせん断試験装置を示す。ポリスチレンフォーム板B $\ell$ のに 置いた底がない型枠に、練混ぜ直後のモルタルを満たして、上面を 平らにした後、型枠を取り去る。一旦圧密した後、試料の厚さを測 $\eta 、$ 板 $\mathrm{Bu}$ とおもり $\mathrm{Wv}\left(\right.$ 総荷重 $\left.P_{v}\right)$ を載せ、別のおもり $\mathrm{W} \mathrm{h}\left(\right.$ 荷重 $\left.P_{h}\right)$ によ って水平方向に載荷した状態で、レーザ変位計により試料のせん断

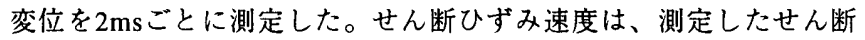
変位より計算によって求めた。

なお、高流動モルタルの試験が可能であり、また、試料にせん断 変形以外の変形が生じることを可能な限り避けるために、今回の実

\begin{tabular}{|c|c|c|c|c|c|c|c|c|}
\hline Series & $W / C$ & $S / C$ & $H A E / C$ & $\begin{array}{l}D_{\max } \\
(\mathrm{mm})\end{array}$ & $\begin{array}{l}m S l \\
(\mathrm{~mm})\end{array}$ & $\begin{array}{l}m S f . \\
(\mathrm{mm})\end{array}$ & $\begin{array}{c}m L t 5-10 \\
(\mathrm{~s})\end{array}$ & Consistency \\
\hline D & 0.62 & \multirow{2}{*}{1.5} & 0.00 & \multirow{2}{*}{0.} & 100 & 155 & $\infty$ & Dry \\
\hline H & 0.55 & & 0.02 & & 140 & 395 & 0.19 & High-flowing \\
\hline
\end{tabular}
験では、試料の厚さを $3 \mathrm{~mm}$ とした。

実験-Iでは、P $P_{v}$ 一定とし、Phを変化させて、Dシリーズの試料

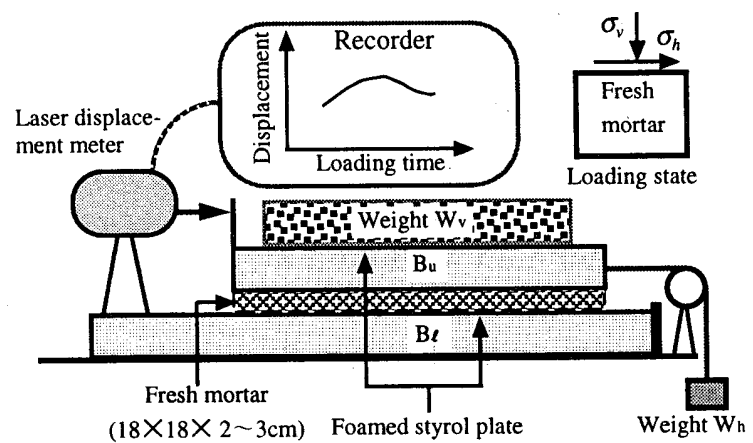

Fig. 2 Apparatus for shearing test

Table 1 Mix proportion and mearsured consistency

[Notes] W/C: Water-cement ratio, $S / C$ : Sand-cement ratio, $D_{\max }$ : Maximum diameter of sand, $m S l:: 1 / 2$-Size slump value ${ }^{16)}, m S f .: 1 / 2$-Size slump flow value ${ }^{16)}, m L t 5 \cdot 10: 1 / 2$-Size L-flow time ${ }^{17)}, H A E / C$ : High-range water-reducing $\mathrm{AE}$ agent-cement ratio. 
について19回、Hシリーズの試料について12回の測定を行 い、垂直応力が一定の条件下で、せん断応力および載荷持続 時間がせん断ひずみ速度に与える影響を検討した。

実験-II では、P $P_{v}$ およびPhをともに変化させて、Dシリーズ について3水準、Hシリーズについて2水準のせん断応力を作 用させて測定を行い、垂直応力の影響について調べた。

\section{2 実験結果および考察}

\section{2 .1 実験-I：載荷持続時間およびせん断応力の影響}

既往の研究 ${ }^{131} に$ 示した手法によって、異なるせん断応力下 のせん断ひずみと載荷持続時間の関係グラフより、試料の粘 弾性限界 $\tau_{e \ell}$ および破壊強度 $\tau_{f}$ (試料の区別は添字H, Dで示す) を求めた。高流動モルタルのHシリーズは、粘弾性限界が非 常に小さくて、粘弾性挙動をほとんど示さないことが確かめ られた。

\section{（1）載荷持続時間の影響}

平均主応力および環境温度が一定の場合の、一定のせん断 応力下における $\gamma / \mathrm{d} t-t$ 関係をFig.3, 4に示す。

Fig.3の高流動モルタル(Hシリーズ)は、粘弾性挙動を示さ ない(Fig.3(a))が、Fig.4の硬練りモルタル(Dシリーズ)の場合 は、粘弾性限界より小さいせん断応力が作用すると、試料 に粘弾性せん断ひずみが生じる。Fig.4(a)では、粘弾性せん 断ひずみ速度は、两対数グラフ上で載荷持続時間の増加と ともに直線的に減少し、式(3-6)、式(4-1)の傾向をよく表し ている。

せん断応力が粘弾性限界以上で破壊強度以下の範囲にある とき、Fig.3(b)およびFig.4(b)によれば、両対数グラフ上で $\gamma /$ $\mathrm{d} t-t$ 関係は、高流動モルタルの場合には、粘塑性ひずみ速度 を表す右下りの直線で現れるのに対して、硬練りモルタルの 場合には、二つの領域が認められる。前述の理論と比べる と、Fig.4(b)の左側の直線は、粘弾性状態のせん断ひずみ速 度を表す式(3-6)、右側の直線は、粘弾塑性状態のせん断ひず み速度を表す式(3-2)の傾向をそれぞれ示している。これらの 結果より、高流動モルタルと硬練りモルタルのいずれの場合 に対しても、粘弾塑性状態の $\mathrm{d} \gamma / \mathrm{d} t-t$ 関係に関する理論解析 結果が実証された。

一方、せん断応力が破壊強度以上になると、Fig.4(c-1)に示 すように、硬練りモルタルのd $\gamma / \mathrm{d} t-t$ 関係は、三つの領域に 区別でき、解析で仮定した三段階の状態が確認できる。両対 数グラフ上で、初めの2本の右下りの直線領域は、粘弾性状 態掞よび粘弾塑性状態におけるひずみ速度を示している。ま た、2種の試料に対して、いずれのd $\gamma / \mathrm{d} t-t$ 関係図(Fig. 3(c-1), Fig. 4(c-1))でも、右側の領域が、Fig. 3(c-2), 4(c-2)に示すよう に片対数グラフ上では直線となり、式(3-5)と一致している。

\section{(2) せん断応力の影響}

Fig.5およびFig.6は、平均主応力と環境温度が一定の場合 におけるせん断ひずみ速度とせん断応力の関係を示したもの である。高流動モルタル(Hシリーズ)の場合には、粘弾性ひずみが生 じなかった(Fig.5(a))が、硬練りモルタルの場合には、Fig.6(a)に示し たように、粘弾性状態におけるせん断ひずみ速度は、せん断応力の

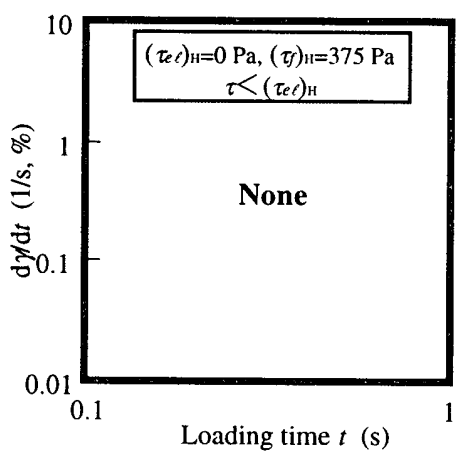

(a) Shearing stress : $0 \mathrm{~Pa}$ (dual-logarithmic chart)

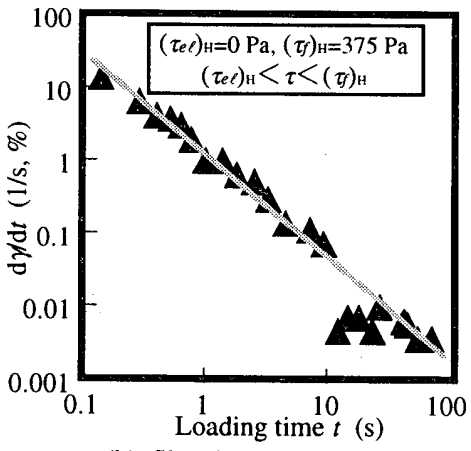

(b) Shearing stress : $313 \mathrm{~Pa}$ (dual-logarithmic chart)

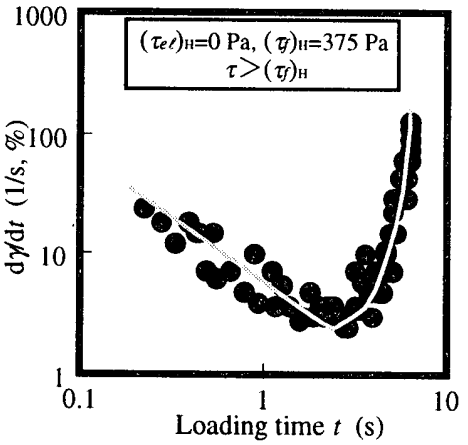

(c-1) Shearing stress : $550 \mathrm{~Pa}$ (dual-logarithmic chart)

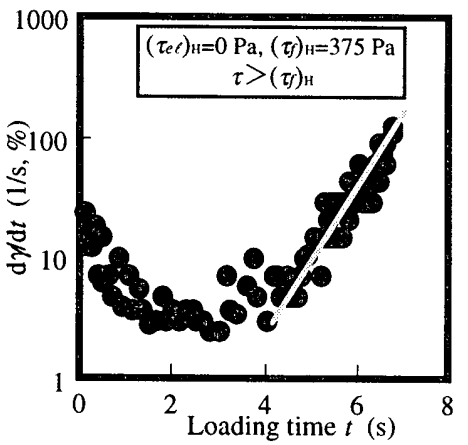

(c-2) Shearing stress : $550 \mathrm{~Pa}$ (single-logarithmic chart)

Fig. 3 Variations of shearing strain rate $\mathrm{d} \gamma / \mathrm{d} t$ of $\mathrm{H}$ series with loading time $t$

$\left(\sigma_{m}=200 \mathrm{~Pa}, T=15^{\circ} \mathrm{C}\right)$

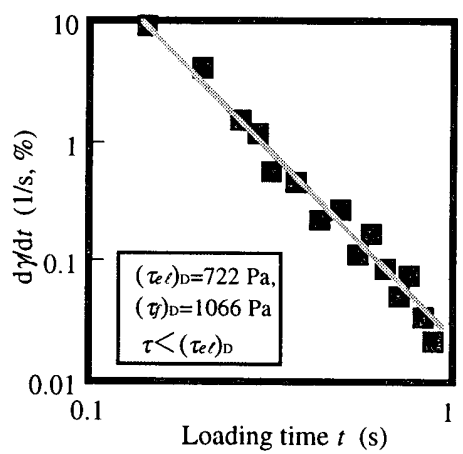

(a) Shearing stress : $706 \mathrm{~Pa}$ (dual-logarithmic chart)

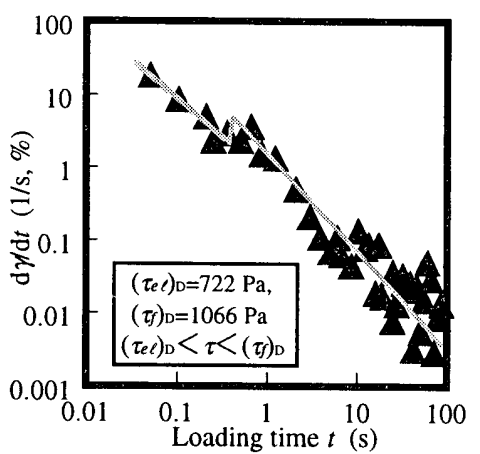

(b) Shearing stress : $993 \mathrm{~Pa}$ (dual-logarithmic chart)

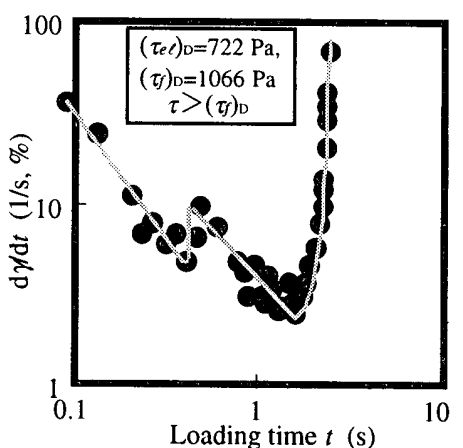

(c-1) Shearing stress : $1194 \mathrm{~Pa}$ (dual-logarithmic chart)

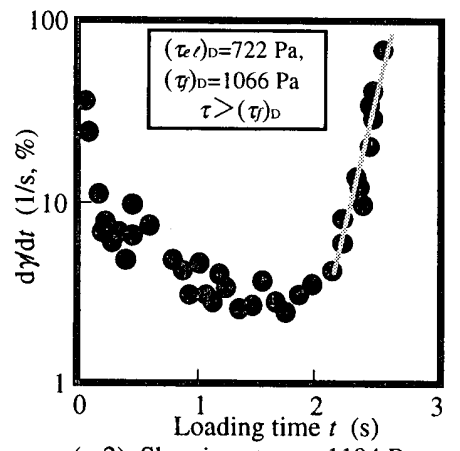

(c-2) Shearing stress : $1194 \mathrm{~Pa}$ (single-logarithmic chart)

Fig. 4 Variations of shearing strain rate $\mathrm{d} \gamma / \mathrm{d} t$ of $\mathrm{D}$ series with loading time $t$

$\left(\sigma_{m}=302 \mathrm{~Pa}, T=15^{\circ} \mathrm{C}\right.$ )

増加に伴って直線的に増加し、式(3-1)と一致している。

一方、Fig.5(b)およびFig.6(b)によれば、軟練り試料および硬練り試 料のいずれに対しても、粘弾塑性状態においては、せん断ひずみ速 


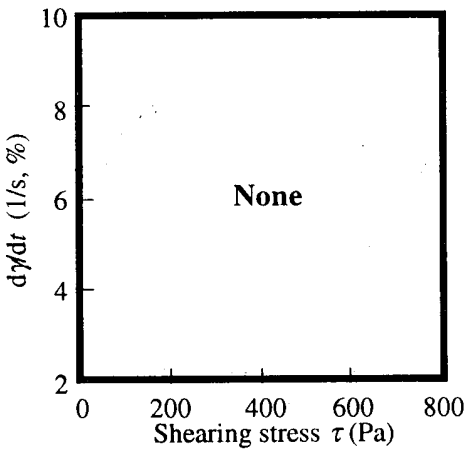

(a) Visco-elastic state

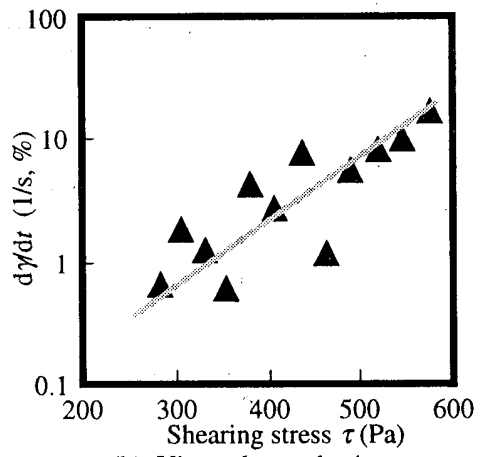

(b) Visco-elasto-plastic state (single-logarithmic chart)

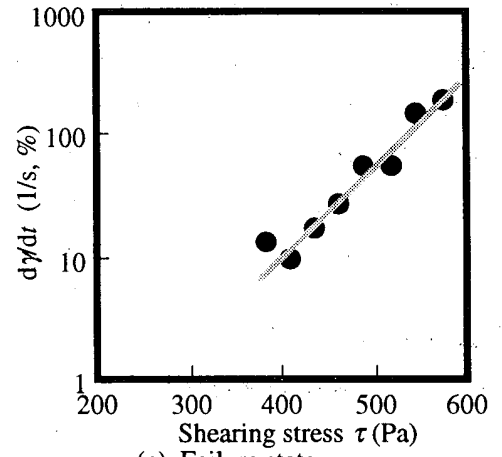

(c) Failure state (single-logarithmic chart)

Fig. 5 Effect of shearing stress $\tau$ on shearing strain rate $d \gamma / d t$ of $H$ series $\left(\sigma_{m}=200 \mathrm{~Pa}, T=15^{\circ} \mathrm{C}\right.$ )

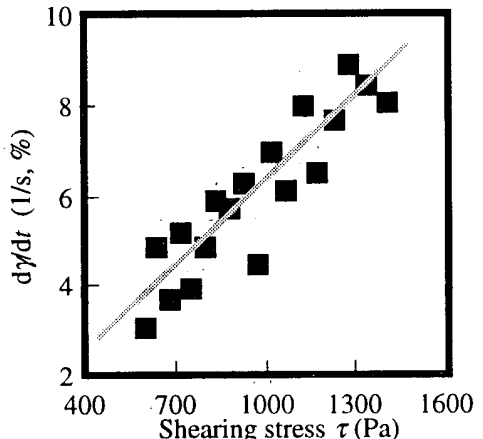

(a) Visco-elastic state

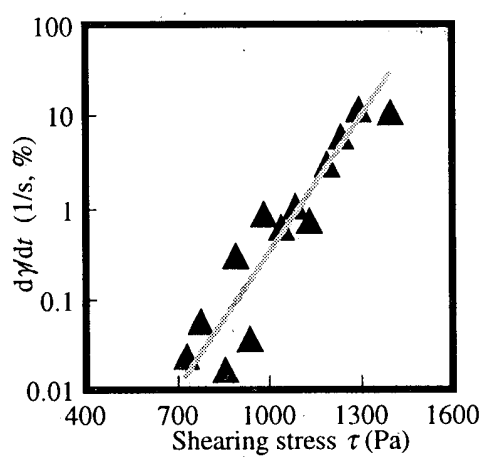

(b) Visco-elasto-plastic state (single-logarithmic chart)

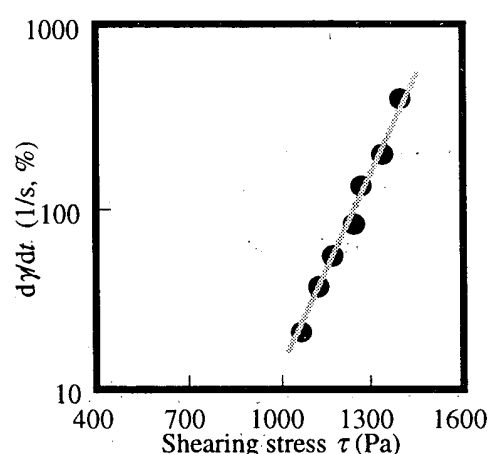

(c) Failure state

(single-logarithmic chart)

Fig. 6 Effect of shearing stress $\tau$ on shearing strain rate $\mathrm{d} \gamma / \mathrm{d} t$ of $\mathrm{D}$ series $\left(\sigma_{m}=302 \mathrm{~Pa}, T=15^{\circ} \mathrm{C}\right)$

度とせん断応力の関係は、片対数グラフ上で右上がりの直線とな ク、式(3-2)の傾向をよく表している。

また、破壊状態では、Fig.5(c)およびFig.6(c)に示すように、せん断 ひずみ速度は、片対数グラフ上でせん断応力とともに直線的に増加 し、見かけの粘性係数は、片対数グラフ上でせん断応力の増加に伴 って小さくなる。この傾向は理論式(3-5)と一致している。

\section{2 .2 実験-II：垂直応力の影響}

Fig.7，8に、せん断ひずみ速度と最大せん断応力面上の垂直応力、 すなわち平均主応力の関係を示す。既往の研究 ${ }^{(4)}$ (15)によって、試料 の応力レベル限界值は、垂直応力とともに増加することがわかって いるため、せん断応力の大きさは予備実験によって決定した。

高流動モルタルが粘弾性挙動を示さないため、この状態の $\mathrm{d} \gamma / \mathrm{d} t-\boldsymbol{t}$ 関係図(Fig.7(a), (b-1), (c-1))は存在しない。硬練りモルタル(Dシリー ズ)の場合には、580Paのせん断応力が作用するとき、試料が粘弾性 挙動のみを示す。このとき、Fig.8(a)によって、 $\mathrm{d} \gamma / \mathrm{d} t-\sigma_{m}$ 関係は、両 対数グラフ上で直線で表される。平均主応力の増加に伴って、せん 断ひずみ速度は小さくなる。これは、理論式(3-10)とよく一致してい る。また、Fig.8(b-1)およびFig.8(c-1)に示すように、最大の粘弾性限 界以上のせん断応力が作用するとき、粘弾性状態における $\mathrm{d} \gamma / \mathrm{d} t-\sigma_{m}$ 関係のグラフも、式(3-10)の傾向をよく表している。

Fig.7(b-2)，(c-2)およびFig.8(b-2)，(c-2)によれば、いずれの試料、お よび最大の粘弾性限界から最小の破壊強度までの範囲にあるせん断 応力に対しても、粘弾塑性状態におけるせん断ひずみ速度は、片対 数グラフ上で平均主応力の増加に伴って双曲線的に減少し、式(3-13)
と一致した。

また、せん断応力が最大破壊強度以上になると、Fig.7(c-3)および Fig.8(c-3)によって、いずれの試料に対しても、破壊状態における $\mathrm{d} \gamma /$ $\mathrm{d} t-\sigma_{i n}$ 関係は、片対数グラフ上で右下りの直線となり、式(3-15)の傾 向を表している。

\section{6. まとめ}

本研究では、フレッシュモルタルの変形抵抗性および粘性係数に 及ほす応力状態および載荷持続時間の影響を定量的に把握すること を目的として、理論的なモデルを仮定して実験的な検討を行った。 本研究によって得られた知見は以下のとおりである。

1) フレッシュモルタルのせん断ひずみ速度および見かけの粘性係 数は、せん断応力または載荷持続時間の増加に伴って、粘弾性、 粘弾塑性㧍よび破壊状態の三段階で変化する。

2) フレッシュモルタルのせん断ひずみ速度は、せん断ひずみの増 加に伴って増加するが、応力状態によって両者の関係は異なり、 それぞれ式(3-1)、(3-3)、(3-4)で表示される。

3) フレッシュモルタルのせん断ひずみ速度は、破壊時点までは載 荷持続時間とともに減少するが、破壊の後、急激に大きくなる。 両者の関係は、それぞれ式(3-1)、(3-3)、(3-4)で表示される。

4) フレッシュモルタルのせん断ひずみ速度は、垂直応力の増加と ともに小さくなる。両者の関係は、式(3-9)、(3-12)、(3-14)で表示 される。

5) 本研究で定義した見かけの粘性係数は、定数ではなく、応力状 


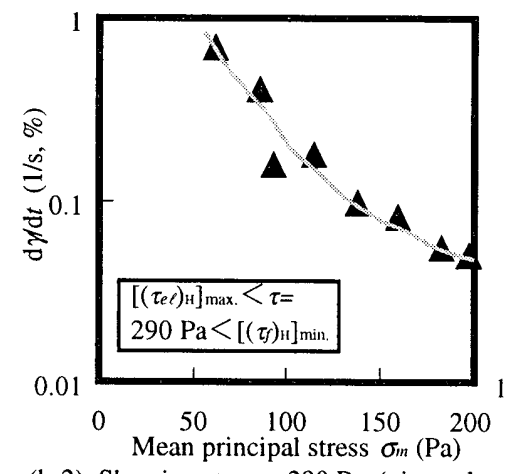

(b-2) Shearing stress : $290 \mathrm{~Pa}$ (visco-elastoplastic state, single-logarithmic chart)

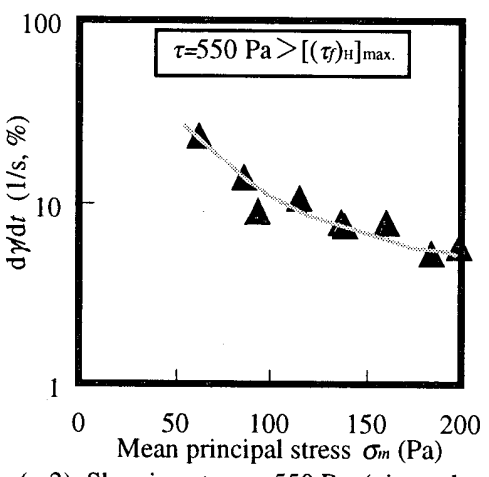

(c-2) Shearing stress : $550 \mathrm{~Pa}$ (visco-elastoplastic state, single-logarithmic chart)

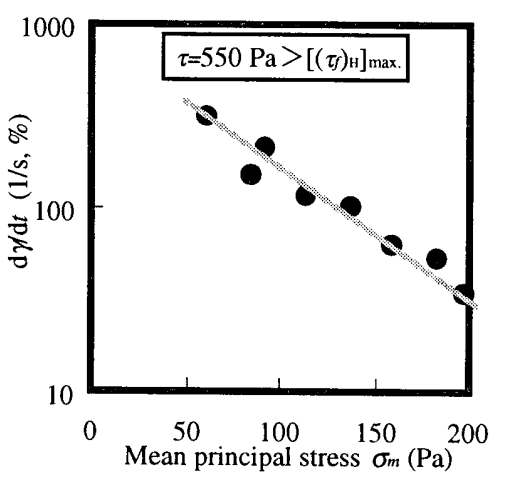

(c-3) Shearing stress : $550 \mathrm{~Pa}$ (failure state, single-logarithmic chart)

Fig. 7 Effect of mean principal stress $\sigma_{m}$ on shearing strain rate $\mathrm{d} \gamma / \mathrm{d} t$ of $\mathrm{H}$ series $\left(T=15^{\circ} \mathrm{C}\right)$

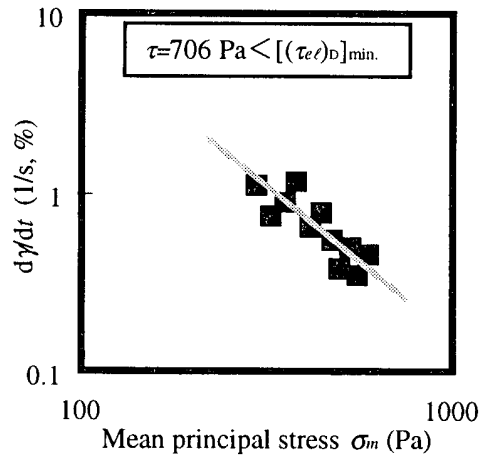

(a) Shearing stress : $706 \mathrm{~Pa}$ (viscoelastic state, dual-logarithmic chart)

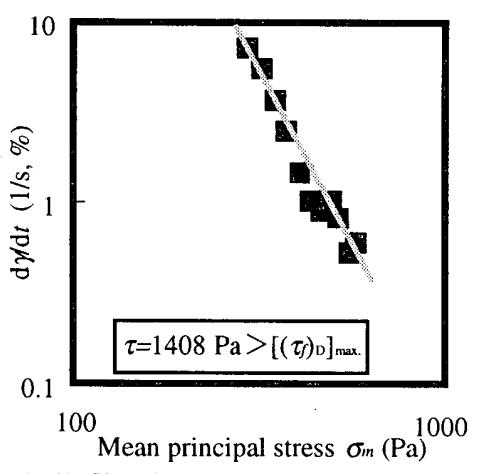

(c-1) Shearing stress : $1408 \mathrm{~Pa}$ (viscoelastic state, dual-logarithmic chart)

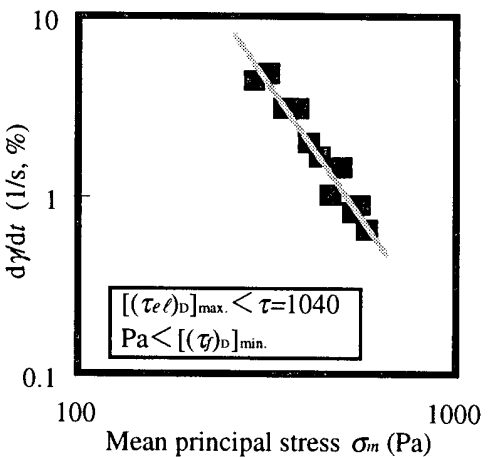

(b-1) Shearing stress : $1040 \mathrm{~Pa}$ (viscoelastic state, dual-logarithmic chart)

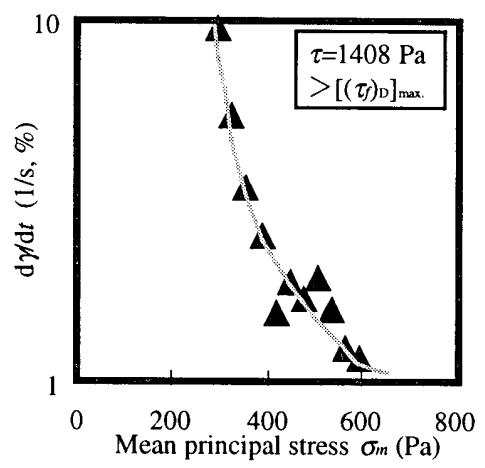

(c-2) Shearing stress : $1408 \mathrm{~Pa}$ (visco-elastoplastic state, single-logarithmic chart)

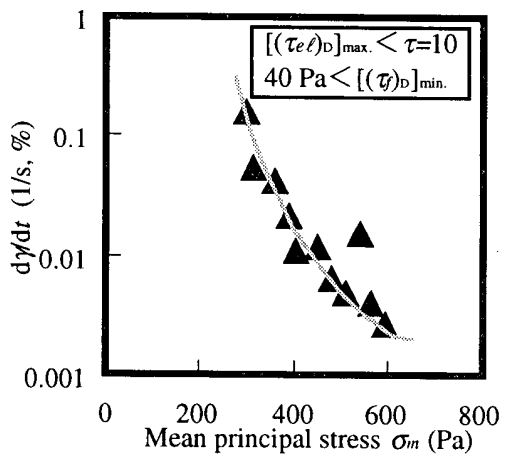

(b-2) Shearing stress : $1040 \mathrm{~Pa}$ (visco-elastoplastic state, single-logarithmic chart)

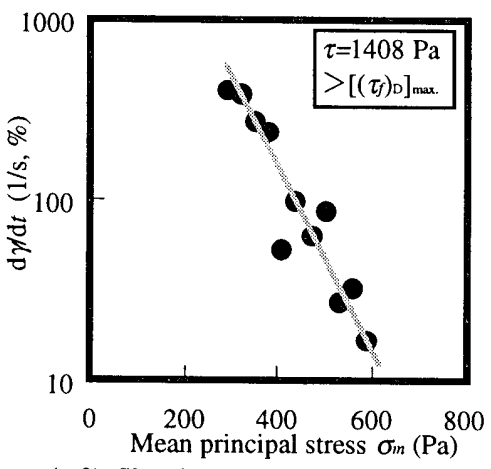

(c-3) Shearing stress : $1408 \mathrm{~Pa}$ (failure state, single-logarithmic chart)

Fig. 8 Effect of mean principal stress $\sigma_{m}$ on shearing strain rate $\mathrm{d} \gamma / \mathrm{d} t$ of $\mathrm{D}$ series $\left(T=15^{\circ} \mathrm{C}\right)$

態および載荷持続時間によって異なり、フレッシュモルタルの変 形抵抗性をよく表現できる。各応力状態および載荷時点における 見かけの粘性係数は、式(4-1)、(4-2)、(4-3)で求められる。

以上、提案した力学モデルに基づいて、フレッシュモルタルのせん 断変形に及ほすす応力状態および載荷持続時間の影響を検討した。本研 究では、応力状態を区分するためのパラメ夕( $20, \tau_{e} \ell, \tau_{f}$ と $\gamma_{e \ell}, \gamma_{f}$ または

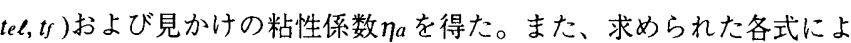
って、フレッシュモルタルの流動性状を定量的に評価することが可能 となった。ただし、各種条件下における情報の蓄積は、今後の課題で ある。

\section{参考文献}

1) 村田二郎：フレッシュコンクリートの鉴動に関する研究, 土木学会論文集,
No.378, V-6, pp.21-23, 1987.2 .

2) Tattersall, G.H. and Banfill, P. F. G. : The Rheology of Fresh Concrete, Pitman Advanced Publishing Program, 356 pp., 1983.

3) 日本コンクリート工学協会：フレッシュコンクリートの力学モデル研究委 員会報告書, pp.3-5, 1996.4.

4) 寺田謙一：せん断ボックス試験に基づくフレッシュコンクリートのレオロ ジー定数の定量化に関する研究, 名古屋大学博士論文, pp.86-102, 1999.2.

5) 森 博䐀：フレッシュコンクリートの流動解析法に関する研究, 名古屋大 学博士論文, pp.69-98, 1989.10.

6）森 博嗣・谷川恭雄：フレッシュコンクリートの構成則に関する研究, 日 本建築学会構造系論文報告集, No.396, pp.9-16, 1989.2 .

7）森 博嗣·田中政史・谷川恭雄：フレッシュコンクリートのせん断変形性 質に関する実験的研究, 日本建築学会構造系論文報告集, No.421, pp.1-10, 1991.3

8) Chong Hu and Francois de Larrard: The Rheology of Fresh High-Performance 
Concrete, Cement and Concrete Research, Vol. 26, No. 2, pp. 283-294, 1996.

9）寺田謙…谷川恭雄・森 博䏤・黑川善幸·三島直生・若林信太郎：せん 断ボックス試験に基づくモデル材料を用いたフレッシュコンクリートのレ オロジー性質に関する研究, 日本建築学会棈造系論文集, No.511, pp. 17-24, 1998.9.

10）水口裕之：フレッシュコンクリートの流動特性に関する基礎的研究, pp $21-42,1984.2$.

11) 後藤廉平：レオロジーとその応用, 共立出版, pp.49-51, 1963.

12）村山朔郎：土の力学挙動の理論, 技報堂出版, pp.1-498, 1990.10.

13）李柱国・谷川恭雄・森 博嗣・黑川善幸：粒子集合体を用いたフレッシ ュモタルの構成則に関する研究，日本建築学会構造系諭文報告集， No.523, 1999.9. (印刷中)

14) 李柱国 · 谷川恭雄·森 博嗣·黒川善幸：セメント系材料のフレッシュ 時の粘弾性限界に関する微視的考察, コンクリート工学年次論文報告集, Vol.19, No.1, pp.661-666, 1999.7.

15）李柱国・谷川恭雄・森 博嗣・黒川善幸：フレッシュモルタルのせん断 破壊限界応力に関する実験的考察, 日本建築学会大会学術講演梗概集 (広 島), A-1, 1999.9. (印刷中)

16）小村理恵·森 博嗣・谷川恭雄・黑川善莘：フレッシュコンクリートの スランピング挙動に関するレオロジー的研究, 日本建築学会構造系論文報 告集, No.462, pp.1-10, 1994.8.

17）米澤敏男：高強度コンクリートの品質管理を目的としたL型フロー 試験法に関する実験的研究, 日本建築学会大会学術講演梗概集, A, pp.263-264, 1988.10

\section{[付録]}

\section{式(3-2)の誘導}

式(2-7)を載荷時間 $t$ について微分して、式(1)を得る。

$$
\begin{aligned}
& \frac{\mathrm{d} \gamma_{p 2}}{\mathrm{~d} t}=\frac{\tau_{r}(2 v+1 / \alpha)}{G_{02}\left[2+\delta-\ln \left\{R_{p}\left(t-t_{e \ell}\right) / \sqrt{1+\left(\tau / \sigma_{m}\right)^{2}}\right\}\right]^{2}} \cdot \frac{1}{t-t_{e \ell}} \\
& =\frac{\tau_{r}(1+2 v \alpha)}{G_{02} \alpha \delta^{2}(1+2 / \delta)^{2}\left[1-\frac{1}{2+\delta} \ln \left\{\frac{R_{p}\left(t-t_{e \ell}\right)}{\sqrt{1+\left(\tau / \sigma_{m}\right)^{2}}}\right\}\right]} \cdot \frac{1}{t-t_{e \ell}}
\end{aligned}
$$

$$
\begin{aligned}
\ln \frac{\mathrm{d} \gamma_{p 2}}{\mathrm{~d} t}= & \ln \frac{\tau_{r}}{G_{02}}+\ln (1+2 v \alpha)-\ln \alpha \delta^{2}-\ln \left(1+\frac{2}{\delta}\right)^{2} \\
& -\ln \left[1-\frac{1}{2+\delta} \ln \left\{\frac{R_{p}\left(t-t_{e \ell}\right)}{\sqrt{1+\left(\tau / \sigma_{m}\right)^{2}}}\right]^{2}-\ln \left(t-t_{e \ell}\right)\right. \\
\doteqdot & \ln \frac{\tau_{r}}{G_{02}}+2 v \alpha-\ln \left(\alpha \delta^{2}\right)-\frac{4}{\delta}+\frac{2}{2+\delta} \ln \left\{\frac{R_{p}\left(t-t_{e \ell}\right)}{\sqrt{1+\left(\tau / \sigma_{m}\right)^{2}}}\right\} \\
& -\ln \left(t-t_{e \ell}\right) \\
= & \ln \frac{\tau_{r}}{G_{02}}+2 v \alpha-\ln \left(\alpha \delta^{2}\right)-\frac{4}{\delta}+\ln \left[\left\{\frac{R_{p},}{\sqrt{1+\left(\tau / \sigma_{m}\right)^{2}}}{ }^{\left(\frac{2}{2+\delta}\right)}\right.\right. \\
& \left.\cdot\left(t-t_{e \ell}\right)^{\left(\frac{-\delta}{2+\delta}\right)}\right] \\
& \div \ln \frac{\tau_{r}}{G_{02}}+2 v \alpha-\ln \alpha \delta^{2}-\frac{4}{\delta}-\ln \left(t-t_{e \ell}\right)(\delta \sigma \text { 値が大きいため) }
\end{aligned}
$$

式(2-7)に示した $\alpha, \delta$ の値を上式に代入して、式(3)を得る。

$$
\begin{aligned}
\ln \frac{\mathrm{d} \gamma_{p 2}}{\mathrm{~d} t}= & \ln \frac{v \tau_{r}^{2}}{G_{02} B_{p}}+\frac{2 \tau_{2 l}\left(\tau_{o}+\tau_{e \ell}-\tau_{r}-\tau\right)}{B_{p} \tau_{r}\left(\tau_{0}+\tau_{e \ell}+\tau_{r}-\tau\right)}+\ln \tau_{2 I} \\
& -2 \ln \left(\tau_{i f}-\tau\right)-\ln \left(t-t_{e \ell}\right)
\end{aligned}
$$

上式の第2項の値は 0 と近似できる。第3、4項の値は式(4),(5)のよ うになる。

$$
\begin{aligned}
& \ln \tau_{21}=\ln \left[\tau_{r} \ln \frac{\tau_{r}}{\tau_{i f}-\tau}+\tau_{e \ell}-\tau_{0}\right] \\
&=\ln \left[\tau_{r} \ln \frac{\tau_{i f}-\tau_{e \ell}}{\tau_{i f}-\tau}+\left(1+v_{0}\right)\left(\tau_{e \ell}-\tau_{0}\right)\right] \\
&=\ln \left[\tau_{22} \cdot\left\{1-\frac{\tau_{r} \ln \left(\tau_{i f}-\tau\right)}{\tau_{22}}\right\}\right] \div \ln \tau_{22}-\frac{\tau_{r}}{\tau_{22}} \ln \left[\tau_{i f}\left(1-\frac{\tau}{\tau_{i f}}\right)\right] \\
& \doteqdot \ln \tau_{22}-\frac{\tau_{r}}{\tau_{22}} \ln \tau_{i f}+\frac{\tau_{r}}{\tau_{22} \tau_{i f}} \tau \\
& こ こ に 、 \tau_{22}=\tau_{r} \ln \left(\tau_{i f}-\tau_{e \ell}\right)+\left(1+v_{0}\right)\left(\tau_{e \ell}-\tau_{0}\right) \\
& 2 \ln \left(\tau_{i f}-\tau\right)=2 \ln \left[\tau_{i f}\left(1-\tau / \tau_{i f}\right)\right]=2 \ln \tau_{i f}-2 \tau / \tau_{i f}
\end{aligned}
$$

式(4)および式(5)を式(3)に代入すると、式(3-2)が得られる。

式(1)の両辺を対数にとっって、近似的に計算すると、式(2)になる。 